\title{
Attitudes to Animal Dilemmas: An Exploratory Comparison Between Mexican and English Children
}

\author{
Laura BARRAZA \\ Deakin University, Melbourne, Vic, AUSTRALIA
}

\begin{abstract}
This research explores some of the factors that influence the relations about empathy and /or rejection that children establish towards some animal species. The role that school has within the social context in these dynamics was considered. Attitudes of young children (aged 7 to 9) from Mexico and England towards specific animal species, examining attitudinal differences not only between cultures, and educational systems, but between species have been compared. Ecological dilemmas involving animals are used as a method to analyse children's constructions of the environment in the field of moral development and conservation. Children expressed more negative attitudes towards spiders and snakes, than towards monkeys and birds. Although these attitudes in themselves are not surprising, the material in this study provides new information on how young children construct their moral ideas on conservation matters through the used of ecological dilemmas. Children's reactions vary according to culture, experience, affiliation for a particular animal and school ethos.
\end{abstract}

Key words: Attitudes, biophilia, children, animals, ecological dilemmas

\section{Introduction}

In the face of rapidly changing environmental conditions there is concern on several fronts about how to respond to them. However there is considerable debate about the extent to which the acquisition of knowledge and understanding of environmental issues necessarily leads to more positive attitudes towards or behaviour in, the natural environment (Posch, 1993; Barraza \& Walford, 2002). There are substantial grounds to recognize not only the connection between attitudes and behaviour but also the connection between educational initiatives and attitude formation. Finding ways to reconnect people to nature is a critical challenge for conservation biologists in this new century (Brewer, 2002). Due to the connections mentioned above, this critical challenge must also be met in the classroom. In this, many conservation biologists are committed to recognizing their responsibility to collaborate with the school community as well as other groups of the society in order to promote broad public awareness to strengthen environmental attitudes, values and actions.

The role of education in the formation of values and social action can be fundamental for successful conservation and management programs (Barraza, 1996; Jacobson \& Marynowski, 1997). Effective solutions to environmental problems require active participation of scientifically and technologically literate citizens (Brewer, 2002).

If we begin with the assumption that effective environmental education needs to be based on children's understandings of the environment, it becomes immediately clear that relatively little is known about that understanding (Loughland, Reid, \& Pectocz, 2002; Barraza \& Cuarón, 2004). Therefore more studies on how children think, learn and apply their knowledge on environmental matters are needed. It is important to identify where children are obtaining their information, and if what they are learning is

ISSN: 2146-0329

*Corresponding Author: Laura Barraza,

E-mail: laura.barraza@deakin.edu.au 
accurate. This information and support provided by conservations biologists could help strengthen environmental education and science teaching programmes (Barraza \& Cuarón, 2004).

\section{Why the focus on dilemmas involving animals?}

Children develop their sense of curiosity at a very early age. For most of them, animals are of special interest and usually attractive. However, the fact for example, that children like cats, because they think they are cute and they like to play with them, does not say anything at all about how they might understand their impact on an ecosystem; nor will it tell you much about how they might or might not relate to the environment more generally.

Ethical dilemmas can provide valuable information on children's values, knowledge and actions. When people are confronted with dilemmas, they find themselves having to come to terms with ambiguities in their own system of beliefs, and own moral values. Dilemmas involving animals are a particular type of moral predicament that individuals have to face specifically when confronted with environmental problems (Barraza, 1996). They are becoming more important, as the magnitude and detrimental effects of human actions on the environment increase. However, little research has been done using dilemmas as an effective method of children's environmental attitudes (Kohlberg, 1984). By using animal dilemmas we can establish some connections between children's preferences for some species of animals and their moral implications towards conservation issues.

\section{Why the focus on biophilia?}

We believe that identifying children's attitudes towards animals at an early age can help educators, parents and biologist identify key aspects for educational and conservation programs. By observing children's interactions with animals we can obtain much information on children's affective, social and cognitive development. A child's perception of animals-as-individuals appears to be less popular, as one move down the line from the bigger mammals to the smaller species of invertebrates (Van Arc ken, 1993). Children's preferences for a particular animal have a strong association with human features (Morris, 1960). Children do not like animals which they think are dangerous and which make unpredictable movements. Snakes and spiders, for instance, were the two most disliked animals by the British children (Morris, 1960). This may be a general cross-cultural pattern. There is a human propensity to fear and elude threatening aspects of nature, particularly those associated with reptiles, such as snakes, and various biting and stinging invertebrates, like spiders (Kellert, 1993).

Attitudes towards wildlife or nature have been studied in different social or cultural contexts (e.g., Kellert, 1983, 1991, 1993; Adams, Newgard \& Thomas, 1986; Kellert \& Clark, 1991; Reading \& Kellert, 1993; Caro, Pelkey \& Grigione, 1994; Musser \& Malkus, 1994; Uzzell 1994; Steel, 1996; Jacobson \& Marynowki, 1997). They have not been assessed, however, with respect to one of the main settings where these behaviours tend to be moulded - schools. Children spend a lot of their time in schools, consolidating their behaviour, during classes and while playing on the grounds. They read school grounds as they read any external environment: as a set of symbols which tell them what they are supposed to 'be' and 'do' and 'think' and 'feel' in that place (Titman, 1994). The appearance of outdoor spaces within a school setting is important for children since they react to different elements related to stimulus, such as, the natural colour of flowers and trees, the texture of leaves, the smell of flowers, the form of fruits, and so forth (Titman, 1994). The appearance of outdoor spaces can stimulate 
positive and/ or negative moral reactions. For example, Titman (1994) found that children are more aggressive amongst themselves as well as towards the environment when they do not have green areas in which to play, or when school grounds are very small.

From a very early age children start making contact with nature. Children explore their surroundings as part of discovering the world. They get to know their environment, touching, feeling, and trying everything to confirm their knowledge. It seems that there is a spontaneous attraction and a positive instinct between children and their world, a phenomenon described by Wilson (1984) as 'biophilia', or the innately emotional affiliation of human beings to other living organisms. If biophilia is the genetic affinity for other lives, why is it expressed in some children and cultures more than in others? and why do some living things seem to 'count' more than others? According to Nabhan and Antoine (1993) there are at least three answers to this question. First, perhaps biophilia is not genetically determined but is a set of learned responses. Second, some human genetic lineages may have been selected for biophilic responses more than others. Third, a child's learning environment greatly conditions the expression of any genetic basis for biophilia, that is, that biophilia is a function of an interaction between teaching and genetics. An alternative explanation is that biophilia is not about fixed traits as Wilson and others believe, that is not genetic at all. Egan (1991) proposes that much of the distressing disregard of nature that we see in many young children is caused by the fact that human potential for feeling a part of nature is too rarely evoked, stimulated and developed in children. This is supported by Ulrich who claims that "Learning is required for acquiring a positive response that is only partly predisposed by genetic factors, and the response is modified by conventional learning, experience and culture" (Ulrich, 1993). In this research an examination is made on how learning, experience and culture can intervene in the process of developing a moral responsibility towards children's attitudes to animals.

\section{Affective and cognitive factors influencing the choice of age group}

Young children from 2 to 7 years of age do not give moral reasons for or understand the rules behind their behaviour (Caduto, 1985). At this stage children react according to their feelings; their affective domain is stronger that their cognitive development. Because I wanted to analyze how children were able to establish connections between their affective domain and their cognitive development when confronted with dilemmas involving animals, slightly older children between 7 and 9 years of age were chosen to work with. These early years seem to be most appropriate for the development of environmental values. The age group was also selected because at this stage the child's mind undergoes a developmental change, both intellectually and socially (Piaget, 1969; Vygotzky, 1978). According to Kohlberg (1984), promoting environmental values at this stage of moral development will help the individual: 1) to internalize the rules and expectations of others, especially those of authorities (conventional moral stage); 2) to differentiate him/herself from the rules and expectations of others, understanding why his/her behaviour is affecting others; and 3) to define his/her values in terms of self-chosen principles (post-conventional moral stage).

According to Buergenthal and Torney (1976) children at this age have been found to be intensely curious about the wider world in all its variety; they are more favourably disposed towards other cultures than many older children; they appear open and flexible in their attitudes to social and political issues such as war, poverty. Perhaps most important for the focus of this study, is that Buergenthal and Torney (1976) found 
that at this stage children are beginning to be aware of and interested in issues to do with what's 'fair', or 'right' at a general level (human rights, Barraza, 2001).

Whereas Buergenthal and Torney (1976) focus primarily on children's attitudes to other people, I was interested in exploring whether, within this developmental process, children form a moral concern towards animals. If so, I wanted to examine the extent to which cultural and education factors played an influential role in this process. In this context, I sought to elicit the immediate reactions of Mexican and English school children to particular situations that I felt would reveal their moral values and concerns towards different animals.

\section{Cultural factors as a focus of analysis}

Because children's moral and environmental attitudes may be influenced by their culture, comparable data were gathered in Mexico and England, two countries with significant cultural and structural differences in their economic development and educational systems [(Mexico: lineal and mostly traditional. England: Interactive programs based on community projects (Barraza \& Walford, 2002)]. Mexico is an emerging country with a high biological diversity (McNeely, Miller, Reid, Mittermeier \&. Werner 1990; Ramamoorthy, Bye, Lot \& Fa, 1993). England, on the contrary, is a developed country with low biodiversity in comparison to Mexico.

\section{Methodology}

\section{Study Sites}

Five schools in Mexico and three in England were sampled. Schools were selected from the following categories: a) primary schools; b) mixed schools (girls and boys); c) day and boarding schools and finally d) schools with varying degrees explicit emphasis with regards to the environment (i.e., the emphases in their orientation and interest on environmental issues).

Boarding schools were included in this study to explore how in the absence of the daily presence of parents the school influences the formation of environmental attitudes in young children. Schools were grouped according to their ethos with respect to environmental policies and whether they were day or boarding schools (Table 1).

'Environmental schools' selected in this study have written environmental policies, demonstrated also by their active role in local, national and international environmental projects. Schools with 'some interest in the environment' were those that manifested a concern on environmental issues, although they were not active in environmental projects, nor had written environmental policies.

Socio-economic level of children in this study varied. Children growing up in different socio-economic levels acquire different cognitive abilities (Gray, 1991) and frequently undergo distinct cultural processes that might well influence general attitudes towards the world around them. Some of these socio-economic differences were considered in this study, although their evaluation was not the main purpose of the study.

\section{Data Collection}

Because perception and moral judgement are such subjective states, it was crucial to test the assessment tools in a pilot study. Two assessment instruments were tested with eight year-old children in a primary school not included in the final study in order to 
evaluate their efficacy in eliciting children's perceptions of the environment and their attitudes towards environmental issues. These tools were: a sentence- completion technique and a narrative description (tell a story). After analysing the results of the pilot work an open-ended questionnaire was applied to 248 children (104 English and 144 Mexican). Open questions are optimal for testing hypotheses about ideas or awareness (Oppenheim, 1992). The questionnaire consisted of four open questions involving issues about moral values and concern for animals. Children in each school were asked to write what they thought would be their immediate reaction to different situations. Questions were related to different groups of animals: invertebrates (spiders), reptiles (snakes), birds, and mammals (monkeys), to test children's relationship with biophilia across a range of species. The questions were:

1. What would you do if you found a spider in the dining room of your house?

2. What would you do if you found a snake in your school's play ground?

3. What would you do if you were at the park, and you found a baby bird that had fallen from its nest?

4. What would you do if somebody offered you a monkey to keep as a pet?

Different settings were chosen to analyse children's degree of exposure with the situation.

\section{Data Analysis}

Based on a content analysis data was coded in order to classify the answers (Barraza 1999, 2001). All answers were registered and categorized according to the type of response. When analysing the children's responses to questions 1,2 and 3 a fivecategory scale was used: 1) destructive, 2) fearing, 3) call for help, 4) unconcerned and 5 ) protectionist. For question 4 , related to the monkey, a different category scale was used: 1) accept, 2) refuse, 3) report to police, 4) ask my parents, and 5) take it to the wild/zoo/vet/RSPCA (Royal Society for the Prevention of Cruelty to Animals). Each of these actions can indicate to what extent young children develop positive, negative and/or indifferent attitudes to situations that generate dilemmas involving animals.

For questions 1 and 2, the negative action was obvious (e.g., to kill), but in the others it was necessary to search for the negative impact and to see it with reference to a cultural context. For example, by recording the reasons that young children gave for accepting or refusing the monkey, it was possible to find out how much information young children in this study had on endangered species, and/or the illegal wildlife trade. Monkey trade is illegal worldwide. In Mexico all species of monkeys are endangered species. In this sense children's answers can provide basic information to the development of environmental education programs.

In the case of finding a baby bird that has fallen from its nest, the attitude of ignoring the animal and not doing anything to help it was considered a negative action (but see discussion).

Schools were evaluated to find out if environmental ones were more effective than the others in children's attitudes towards animal dilemmas.

Analysis of Deviance procedures using GLIM 3.77 (Royal Statistical Society, 1985) was used to perform statistical analysis. As indicated in Crawley (1993), a Poisson error and a logarithm link function were used for count dependent variables. In the cases where needed, re-scaling was made to avoid over dispersion problems (Crawley, 1993). 
Comparisons were made contrasting Mexico versus England and between schools with different ethos. A probability of $5 \%(p=0.05)$ was considered as the cutting point for statistical significance.

\section{Results}

What would you do if you found a spider in the dining room of your house?

Some examples of children's responses are reported in Table 2. Overall, $44 \%$ of children in the study group said they would kill the spider, $10 \%$ manifested a fearing attitude, $7 \%$ would call for help, $6 \%$ would take no notice, and $32 \%$ would show a protectionist attitude towards the spider. All English children were significantly more likely than all Mexican children to have a positive reaction towards the spider or to pay no attention/notice to it; most of them would pick it up and put it outside ( $X^{2}=60.97$, $\mathrm{df}=4, p<0.0001$; Fig.1a; Tble 2). Children from Mexican schools with environmental policies tended to be more protective $\left(X^{2}=48.88, \mathrm{df}=8, p<0.001\right.$; Fig. $\left.1 \mathrm{~b}\right)$. However in the case of the English children the school ethos was not a significant factor $\left(X^{2}=\right.$ $5.129, \mathrm{df}=2, \mathrm{~ns})$. The interaction between country, school ethos and attitudes towards the spider is significantly different $\left(X^{2}=30.76, \mathrm{df}=8, p<0.001\right)$. It is not clear to suggest that school might be influencing children's attitudes towards spiders. It is more probable that cultural context through exposure have a greater effect on children's attitudes (see discussion). 


\section{spider}

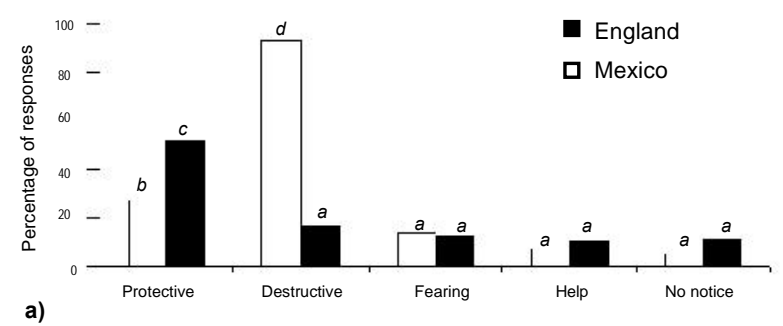

a)
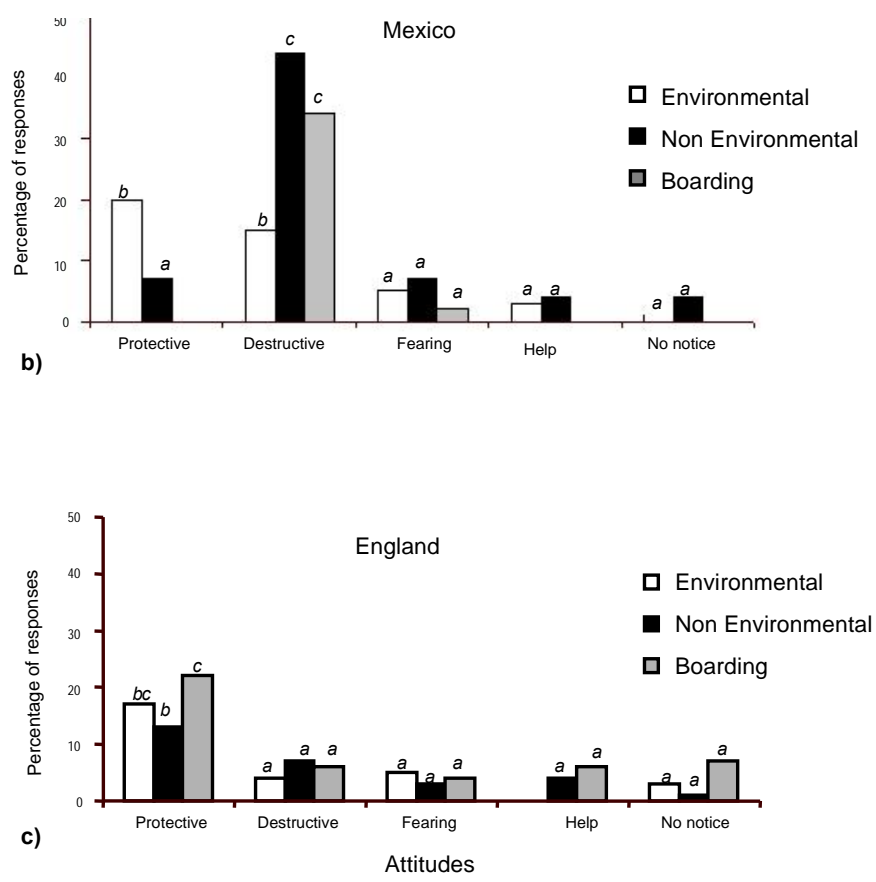

Figure 1.

Children's reaction to a spider they found in the dining room of their house. a) Countries; b) Mexican schools ethos; c) English schools ethos. Significant differences among countries and school ethos in each country are indicated by different letters (the same letter indicates no significant differences). 
What would you do if you found a snake in your school's play ground?

Typical responses are shown in Table 2. For both countries the most frequent answer was to call for help (i.e., to get a teacher or a staff member). Overall results showed that children's reactions towards snakes were more positive than negative, with $66.7 \%$ expressing a positive action (this total includes protectionist, call for help, and no notice attitudes). Mexican children expressed more negative or fearful attitudes towards snakes; almost $20 \%$ of them said they would kill it, while only $3 \%$ of English children mentioned they would do so $\left(X^{2}=40.35\right.$, df=4, $p<0.0001$; Fig. 2a; Table 3). Children from environmental schools in England and in Mexico were less likely to give destructive responses than children from boarding schools in each country. Mexican children from schools with no environmental policies tend to call for help when finding the snake in a greater proportion than schools with environmental policies $\left(X^{2}=26.78\right.$, $\mathrm{df}=8, p<0.001$; Fig. $2 \mathrm{~b}$ ). Once again, cultural context through exposure seems to have a greater effect on children's attitudes than school policies. 


\section{Snake}
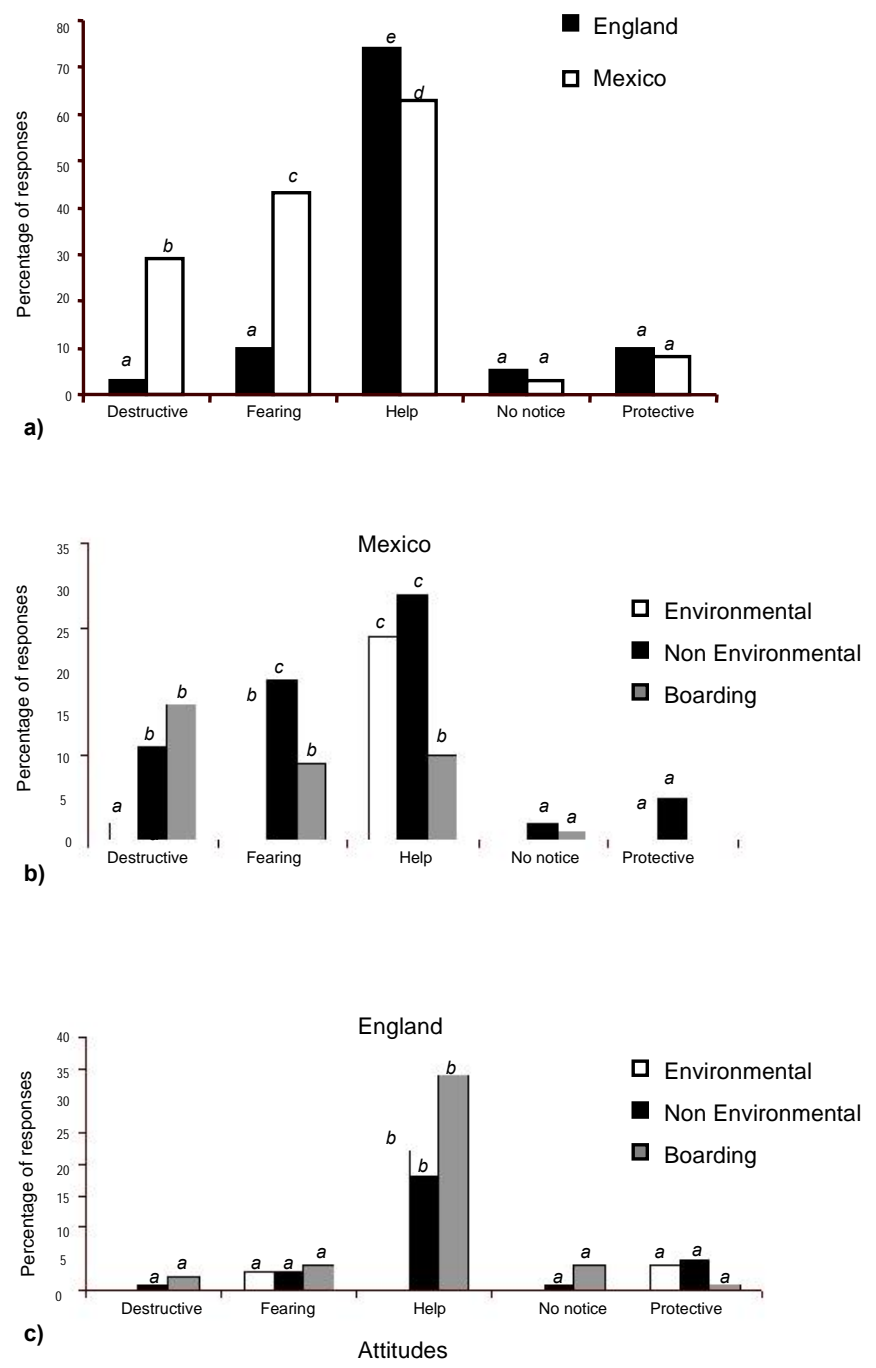

Figure 2.

Children's reaction to a snake they found in their school playground. a) Countries b) Mexican schools ethos; c) English schools ethos. Significant differences among countries and school ethos in each country are indicated by different letters. 


\section{Table 3.}

Analysis of deviance to test the single and interactive effects of attitude and country of origin on the frequencies of environmental dilemmas related to the children's perception of four animals (asterisks indicate interaction).

\begin{tabular}{|c|c|c|c|c|c|}
\hline Animals & Factor & $\begin{array}{c}\text { Deviance } \\
\left(\mathrm{X}^{2} \text { approx. }\right)\end{array}$ & $r^{2}$ & $\mathrm{df}$ & $P$ \\
\hline Spider & $\begin{array}{l}\text { Attitude } \\
\text { Country } \\
\text { Attitude*Country } \\
\text { Error } \\
\text { Total }\end{array}$ & $\begin{array}{r}142.6 \\
7.85 \\
60.97 \\
0 \\
211.39\end{array}$ & $\begin{array}{r}67.4 \\
3.71 \\
28.84 \\
0\end{array}$ & $\begin{array}{l}4 \\
1 \\
4 \\
0 \\
9\end{array}$ & $\begin{array}{l}\leq 0.0001 \\
0.005 \\
\leq 0.0001\end{array}$ \\
\hline Snake & $\begin{array}{l}\text { Attitude } \\
\text { Country } \\
\text { Attitude*Country } \\
\text { Error } \\
\text { Total }\end{array}$ & $\begin{array}{r}191.7 \\
7.85 \\
40.35 \\
0 \\
239.88\end{array}$ & $\begin{array}{r}79.91 \\
3.27 \\
16.82 \\
0\end{array}$ & $\begin{array}{l}4 \\
1 \\
4 \\
0 \\
9\end{array}$ & $\begin{array}{l}\leq 0.0001 \\
\leq 0.01 \\
\leq 0.0001\end{array}$ \\
\hline Bird & $\begin{array}{l}\text { Attitude } \\
\text { Country } \\
\text { Attitude*Country } \\
\text { Error } \\
\text { Total }\end{array}$ & $\begin{array}{r}354.1 \\
9.5 \\
40.15 \\
0 \\
403.75\end{array}$ & $\begin{array}{r}87.7 \\
2.35 \\
9.94 \\
0\end{array}$ & $\begin{array}{l}3 \\
1 \\
3 \\
0 \\
7\end{array}$ & $\begin{array}{l}\leq 0.0001 \\
\leq 0.005 \\
\leq 0.0001\end{array}$ \\
\hline Monkey & $\begin{array}{l}\text { Attitude } \\
\text { Country } \\
\text { Attitude*Country } \\
\text { Error } \\
\text { Total }\end{array}$ & $\begin{array}{r}281.6 \\
7.8 \\
26.03 \\
0 \\
315.46\end{array}$ & $\begin{array}{r}89.26 \\
2.47 \\
8.25 \\
0\end{array}$ & $\begin{array}{c}5 \\
1 \\
5 \\
0 \\
11\end{array}$ & $\begin{array}{l}\leq 0.0001 \\
\leq 0.01 \\
\leq 0.0001\end{array}$ \\
\hline
\end{tabular}

What would you do if you were in the park, and you found a baby bird which had fallen from its nest?

Examples of responses are shown in Table 2. In most of their answers (94.3\%) a positive action was involved. Overall, $77.3 \%$ of Mexican and English children manifested a protectionist attitude towards the bird, $17 \%$ would call for help (vet, RSPCA), and $4.5 \%$ would take no notice. Only $1.2 \%$ showed a destructive attitude. None of the children showed a fearing response to the bird. English children would call for help in a greater proportion than Mexican children $\left(X^{2}=40.15, d f=3, p<0.0001\right.$; Fig. 3a; Table 3). There was a high tendency of Mexican and English children to try to save the baby bird and put it back in its nest, or take it home and look after it until it recovered. These two elements, protection and care, were constantly mentioned. However Mexican children would protect the bird more than English children. Something mentioned only by Mexican children was the possibility of finding the baby 
bird dead. In such cases children said they would bury it. This action was considered a positive attitude.

There were not significant differences found between children attitudes and the school ethos. For this dilemma, children attitudes were not determined by the school ethos. Mexican children from schools with no environmental policies were more protectionist than children from schools with environmental policies $\left(X^{2}=4.008, d f=6, n s ;\right.$ Fig.3b). English children from boarding schools manifested a more protectionist attitude than English from other schools ethos $\left(X^{2}=6.475, \mathrm{df}=6, \mathrm{~ns}\right.$; Fig.3c). 


\section{Bird}
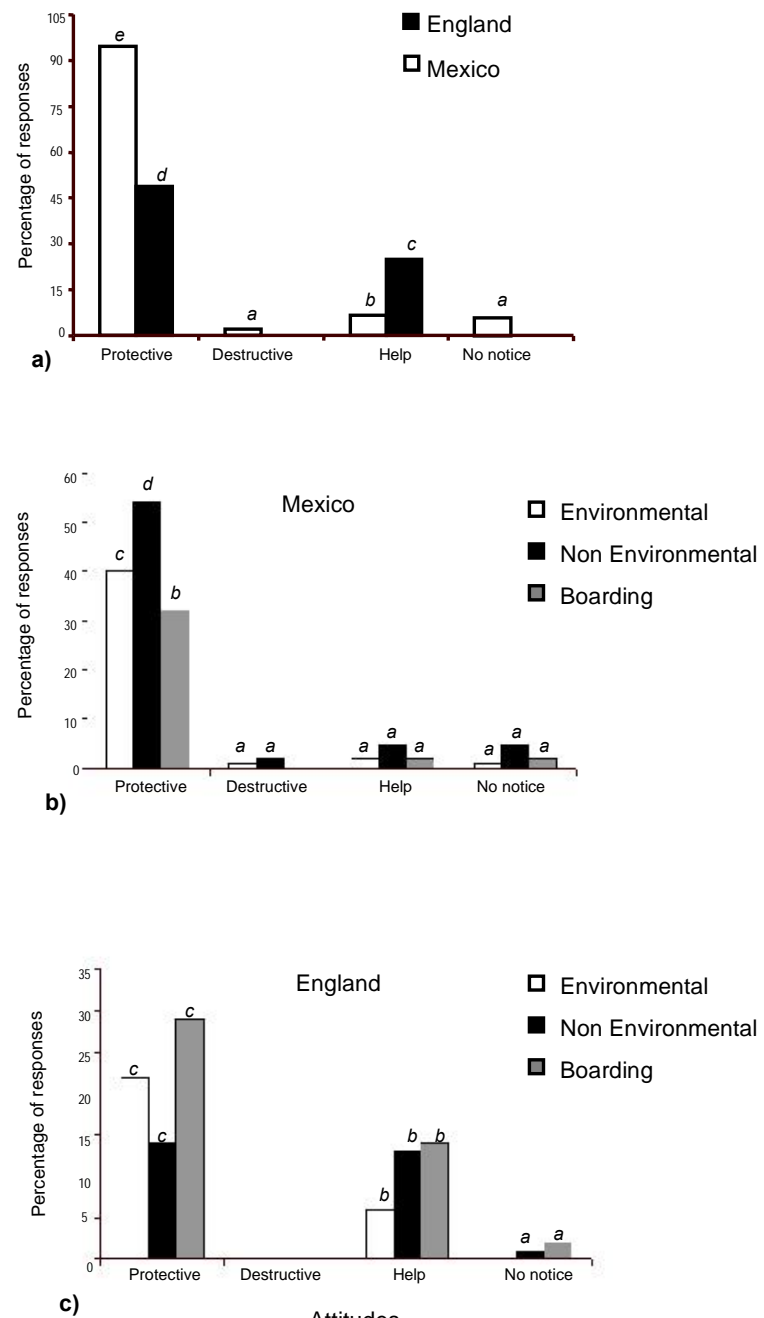

Figure 3.

Children's reaction to a baby bird that had fallen from its nest. a) Countries; b) Mexican schools ethos; c) English schools ethos. Significant differences among countries and school ethos in each country are indicated by different letters.

What would you do if somebody offered you a monkey to keep as a pet? 
$48 \%$ of Mexican and English children said they would refuse the offer (Fig. 4a). Whilst $32 \%$ said they would accept the animal. Next in importance were the children that would take it to either a zoo, a vet, to the RSPCA or into the wild, and those who would ask their parents. Some of the reasons why children of this age group would refuse to have a monkey were: "it's not nice for the monkey"; "it is cruel to keep pets"; "lack of space"; "it could be dangerous"; "they live in trees"; "a monkey is not a domestic animal"; "it's a wild animal"; "they are harmful"; "it's a struggle"; "too much a risk"; "they are too dirty"; "they are naughty"; "I don't like them".

A larger proportion of Mexican children said they would keep the monkey with them. English children were more likely than Mexican children to take the monkey either to a $z 00$, or a vet, or to the RSPCA or into the wild $\left(X^{2}=26.03, d f=5, p<0.0001\right.$; Fig. 4a).

Overall children from schools with environmental policies in England and in Mexico were less likely to accept the monkey as a pet. Also, a larger proportion of children from schools with environmental policies in England and in Mexico would take the monkey to a zoo, a vet, or into the wild. Even though the results from this dilemma show a slight tendency from children of environmental schools, to reject in a larger proportion the monkey as a pet, no interaction was found between school ethos and attitudes $\left(X^{2}=15.36, d f=10, n s\right)$. However, in the particular case of the Mexican schools the opposite was found. Mexican children from schools with no environmental policies refused the monkey in a greater proportion than children from environmental schools (Fig. 4b). In this particular case, the Mexican school with no environmental policies has a strong moral scheme program as part of its curricula. In the case of the English schools significant differences were found only between attitudes and not between school ethos $\left(\left(X^{2}=25.29, d f=3, p<0.0001\right.\right.$; Fig. 4c). Only in the case of children's reactions to the monkey dilemma did we find a significant relationship between school ethos and students' attitudes. $\left(X^{2}=15.61, d f=8, p<0.05\right)$. The school policy seems not to determine children's attitudes - an issue to which I return in the discussion. 

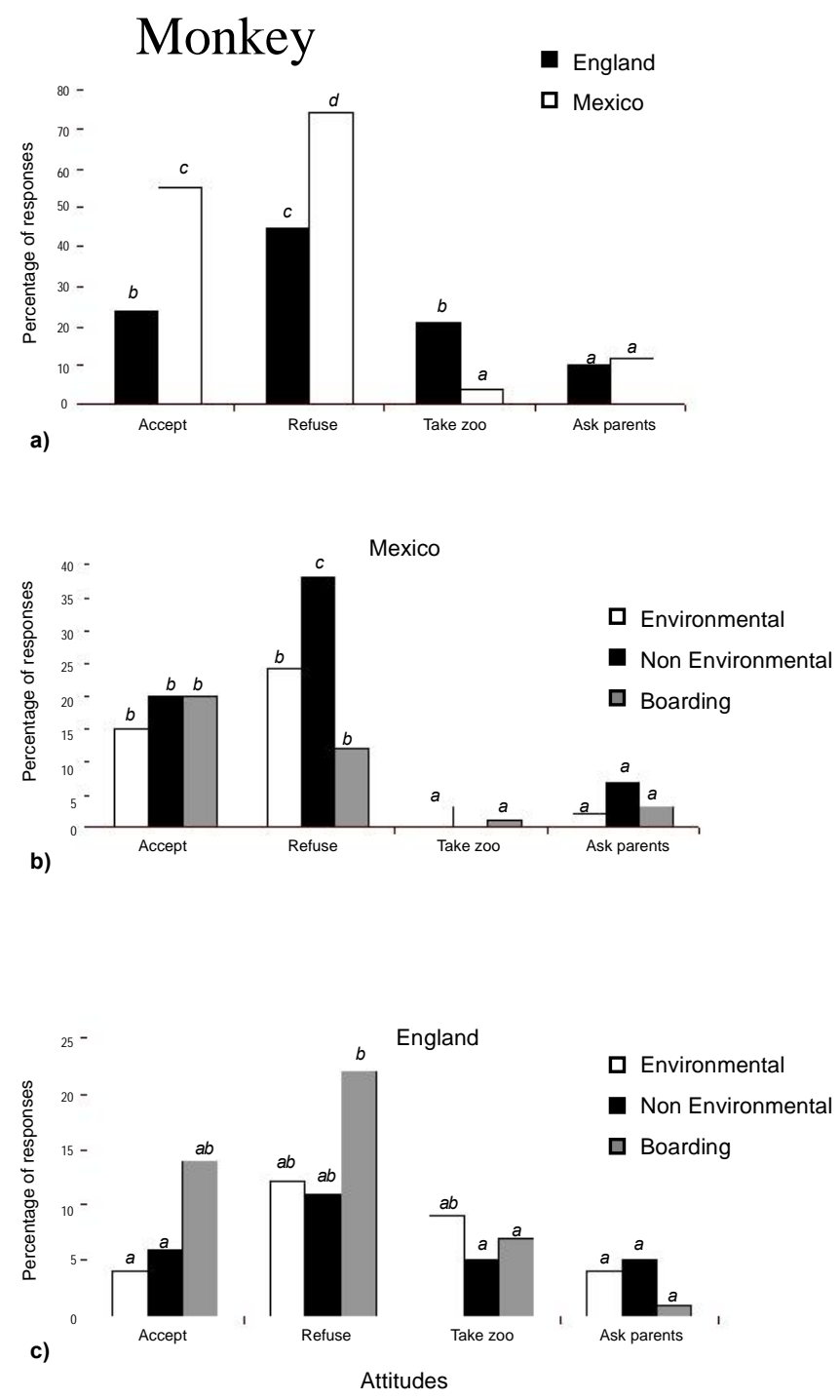

Figure 4.

Children's reaction when a monkey was offered to them as a pet. a) Countries; $b$ ) Mexican schools ethos; c) English schools ethos. Significant differences among countries and school ethos in each country are indicated by different letters. 


\section{Discussion}

What the focus on dilemmas in particular has revealed?

Through the used of dilemmas Mexican and English children in this study manifested a sense of responsibility and ethical concern towards animals. There was a variation according to the dilemma, the species and the context. A direct relation between the dilemma and the species associated with biophilia was found. In the case of spiders and snakes children showed more negative attitudes.

Children in this study form a moral concern towards animals. Besides the ethical concern showed by children in their dilemmas, children expressed their knowledge about certain moral and ecological implications particularly about the bird and the monkey dilemma (e.g. many children gave important ecological reasons of why monkeys were not good pets). A certain level of morality in a society can be reflected through the used of dilemmas. Children answer to behavioural codes determined by society. In this study clearly the socio-cultural context was a determinant factor in children's attitudes towards animals. Overall English children expressed more respect and a sense of protection towards animal's species than Mexican children did.

The use of ecological dilemmas is a valuable tool to associate knowledge, attitudes and values that children manifested towards the environmental crisis.

\section{Cultural differences in children's attitudes towards animals}

Although as expected from the existing literature, it was not surprising to find that both English and Mexican children expressed more negative attitudes to snakes and spiders than to monkeys and birds, it is worth noting that Mexican children expressed a more destructive attitude towards the spider (63.6\%) than did English children (16.6\%). An important aspect to consider is the likelihood of a child finding a venomous spider in either country. For Mexican children the chance of finding a venomous spider in their homes is considerably higher than for English children. This may well be an indicator of why Mexican children have more negative reactions. These findings agree with previous research. Studies on human attitudes toward invertebrates (Kellert, 1993) reveal that the general public largely expresses feelings of aversion, dislike, or fear towards most invertebrates, particularly insects and spiders. Children and females tend to have higher levels of anxiety toward invertebrates (Hardy, 1988). In this study over half of the children had a negative attitude to spiders. It seems that for most children, spiders and insects are organisms deserving no moral consideration (Lockwood, 1987). This view can justify why for so many people it is acceptable to kill spiders and many other invertebrates.

Snakes were the second group of animals that, as expected, children rejected. This confirms adult's negative attitudes towards reptiles, particularly snakes (Morris, 1960; Gray, Larson \& Braunhardt, 1979; More, 1979; Kellert, 1979, 1980; Wilson, 1993). Again, the negative attitude shown by Mexican children to the snake is considerably higher than the one shown by English children; $50 \%$ versus $13 \%$, respectively. About $14 \%$ of the snake species of the world occur in Mexico (Flores-Villela, 1993a). There are about 320 species of snakes (Flores-Villela, 1993a), of which 60 (19\%) are venomous (Flores-Villela, 1993b). In England, by contrast, there are only three species of snakes, which are rarely seen, only one of which is mildly venomous. Therefore, the probability and the risk of having an encounter with a snake plus a dangerous one in a school or in a house are much higher in Mexico than in England. 
In the case of the baby bird that had fallen from its nest, children were more likely to express a positive attitude towards it. Nevertheless 3\% of the English children and $5 \%$ of the Mexican children said they would just ignore it. It is possible that some children have been taught that the best thing to do when finding young wild animals is to leave them alone. The answer, "leave it alone" (without stating as a reason that it is best for the animal) or "would not do anything" was defined as a negative action. Children at this age start getting involved with the outside world, they enjoy looking after others (people and animals), and most of all, they like taking care of animals (Laucks, 1981). This sense of protection can tell us, in a way, how sensitive a child can be to an animal. Most of the children in this survey expressed a degree of compassion towards the bird, showing their concern to help it. According to Wilson (1993) children who throw stones at birds and children who feed birds are both responding to what may be an innate tendency to focus their attention on living things. The choice of behaviour used to engage the animal in the interaction is different and is a learned behaviour (Wilson 1993).

In this study the majority of children from 7 to 9 years old expressed their concern about keeping monkeys as pets. Keeping monkeys as pets is still common in Mexico (Cuarón, 1991, 1997). There are three species of monkeys in the country: spider monkey (Ateles geoffroyi), and two species of howler monkey (Alouatta palliata and $A$. pigra). All three species are considered to be threatened. Some of the main reasons why the species are endangered are hunting and the pet trade (Cuarón, 1991). Poachers usually kill the mother to capture the baby so that they can sell them as pets. Some of these problems have been addressed by the children, through this question, showing that even young children have some knowledge of the implications of having wild animals as pets. Mexican children however, were more likely to accept the monkey $(37.6 \%)$ than English children (23.5\%). One possible explanation for this could be that Mexican children are more familiar with seeing monkeys in houses; therefore it is much easier to acquire monkeys than it is in England.

\section{Children's attitudes and biophilia}

Some other cultural differences were found, particularly in those cases where children were involved with animals they dislike (e.g., snakes and spiders). Mexican children appeared to have more negative attitudes towards these animals. According to Wilson (1993) biophilia could have developed from biocultural evolution, in which culture grew under the effect of hereditary learning propensities, as the genes prescribing the propensities were spread by natural selection in a cultural context. Rapoport (1978) suggests that the relationship between environmental activities and the rules and meanings that accompany them is strongly conditioned by culture. In this study, Mexican children's could fear to spiders and snakes as a response shaped by a cultural and biological context. From a very early age they learn that spiders and snakes can be very dangerous. They develop a sense of cautiousness towards these animals because they are more at risk from them. Another explanation can be that simply spiders and snakes are animals not worthy of biophilic concern.

\section{Effects of school environmental ethos}

Results in this study reveal that children's attitudes towards situations involving animal's dilemmas were more strongly influenced by experience and culture, than by the school ethos itself. A revealing result was that I did not found a direct relation between the school ethos and children's attitudes. Although in some cases children 
from environmental schools showed more positive attitudes towards animals, overall the attitude was determined by biophilia and the social context of the children. There was much greater variability among Mexican schools than among English schools. This was due in large part to Cave School. This Mexican boarding school has a strong emphasis in providing housing to orphan and underprivileged children, and their teaching capabilities are limited. Its performance contrasts with all the other schools in this study. Children from the Mexican boarding school manifested more negative attitudes towards animals, than children from all other schools.

As well as policy and resource matters, the issue of classroom practice needs to be considered. Differences in practice within the Mexican and English educational systems may also help to explain why children from two countries respond differently to environmental issues and have differing amounts of knowledge. This includes the dominant pedagogical approach, the style of teacher- training, methodological tools, the amount of resources available overall, but most important is the cultural context (Barraza \& Walford, 2002). Many Mexican teachers are most comfortable in their classroom practice when providing the information about the environment in a oneway, top-down style and it is common to find them using this traditional and didactic method in primary schools, and not giving children an active role in the learning process (Barraza \& Walford, 2002). In England, it is observed, more emphasis is given to practical activities when educating about the environment. Teachers usually act as 'managers' or 'consultants' for such learning, rather than providing a didactic lead. Their own teacher-training courses have equipped them with the skills and confidence to do this.

The proclamation of the decade of education for sustainable development by the United Nations has placed education in general and environmental education in particular, at the front of a future full of important and uncertain meanings (Caride, 2005). The legitimating of education for sustainable development in the educational mainstream is a first step which can be followed by reformation and transformation of the educational system itself at the micro-level - that of schools - and at the macro-level of policy development and implementation (Barraza, Duque-Aristizábal \& Rebolledo, 2003).

Not finding a direct relation between the school ethos and children's attitudes will encourages us to work closely with the transformation of environmental policies in the school system, including a strategy for parents, teachers and children. The formation of ethical and environmental values starts at home. Parents have a significant role in the development of their children's environmental education (Barraza, 2001; Barraza \& Cuarón, 2004). Their role, together with teachers is fundamental for the promotion of environmental values, attitudes, knowledge and active participation.

One of weaknesses of this study was probably not doing an analysis considering gender. It would have been interested to know if girls at this age (7-9 years of age) have a more strong sense of ethical concern towards animals than boys.

\section{Conclusions}

It is not possible to draw definite conclusions without further research, but this preliminary work leads us to believe that when children are exposed to situations involving dilemmas with animals their reactions vary according to four major factors: 1) culture; 2) experience; 3) affiliation for a particular animal; and 4) school ethos.

Cultural differences affect children's perception and attitudes towards animal-related issues. The symbolic meaning of animals depends on the biological as well as the 
cultural context, in which biophilia may play an influential role. The symbolizing process can enhance positive or negative affiliation. Mexican children in particular seem to have learned to develop fear and to be cautious of more animals than English children. Experience and risk of exposure, we feel, influence children's attitudes towards these animals. In the case of Mexican children, 'snakes and spiders' represented a major perceived danger in their lives, simply, we suggest because of greater biological diversity they encounter in their daily lives. The affinity and preference that children manifested towards animals is connected with their human values.

While in this study school ethos was not statistically determining factor regardless children's attitudes, nonetheless children from schools with environmental policies in general were more likely to develop positive attitudes towards animals - as shown by their responses to spiders (fig.1ab); snakes (fig.2bc) and monkey (fig.4bc). However, the development of effective environmental policies in all schools needs to be considered in order to promote an environmental knowledge and awareness in the school population. Greater importance should be given to education programs in conservation biology. According to Sterling (2001) the ecological approach facilitates integrative thinking. Such thinking is systematic rather than linear, integrative rather than fragmentary. It is more concerned with process than things, with dynamics than linear cause-effect, and with pattern, rather than detail.

Identifying types of environmental attitudes is an important step towards promoting or reinforcing positive behaviours through environmental education in diverse contexts, particularly at home and school. Education at all levels must be developed to enable people to understand the interrelationships between humans and the environment.

\section{Acknowledgments}

I am deeply grateful to $B$. Bodenhorn for discussion and suggestions on the manuscript. Also to N. Anten, H. Arita, L.A. Bojorquez-Tapia, A. Carkeek, M.P. CejaAdame, A.D. Cuarón, D. Pérez-Salicrup, M. Martínez-Ramos, R. Walford and I. Robottom for their valuable comments. Thanks to M. Martínez-Ramos and J. Benitez for assistance using GLIM. My deepest gratitude to L. López-Toledo for his valuable help with GLIM and in preparing the figures. Thanks to the staff and children of the schools in England and Mexico who participated in this study: Centro Educativo Morelia, Colegio Avante, Colegio Bilbao, Coton School, Escuela Bartolomé Cosío, King's College School, Park Street School, and one Mexican Boarding school. Finally, thanks to the Consejo Nacional de Ciencia y Tecnología (CONACYT), Mexico, and Churchill College, Cambridge, U.K., for financial support.

\section{Biographical statement}

Laura Barraza. Is currently a Senior lecturer at Deakin University, Melbourne Australia. She has a $\mathrm{PhD}$ in Environmental Education from the University of Cambridge, U.K.

Her current research focuses on Science education; Socio-scientific issues; Traditional and Indigenous knowledge systems; Perceptions, attitudes, and knowledge about the environment in different cultural settings; Cognitive processes involved in the acquisition and incorporation of environmental knowledge 


\section{References}

Adams, C. E., Newgard, L., \& Thomas J.K. (1986). How high school and college students feel about wildlife. American Biology Teacher. 48, 263-267.

Barraza, L. (1999). Children's Drawings about the Environment. Environmental Education Research. 5 (2), 55-66.

Barraza, L. (2001). Perceptions of social and environmental problems by English and Mexican children. Canadian Journal of Environmental Education. 6, 138-152.

Barraza, L. (2001). Environmental values start at home: Parents and their role in the development of values. Journal of Environmental Education and Information. 20, 239256.

Barraza, L. and Walford R.A. (2002). Environmental education: A comparison between English and Mexican school children. Environmental Education Research. 8 (2), 171-186.

Barraza, L. 2002. Los animales y su atractivo para los niños. Especies. 11(5), 25-27.

Barraza, L., A.M. Duque-Aristizábal \& G. Rebolledo. 2003. Environmental Education: from policy to practice. Environmental Education Research. 9 (3), 347-357.

Barraza, L. and Cuarón A.D. 2004. How values in education affect children's environmental knowledge. Journal of Biological Education. 39(1), 18-23.

Barraza, L. 1996. Environmental knowledge and attitudes of English and Mexican school children. Ph.D. Dissertation, University of Cambridge, Faculty of Education. Cambridge, U.K

Brewer, C. 2002. Conservation education partnerships in schoolyard laboratories: A call back to action. Conservation Biology. 3, 577-579.

Buergenthal, T. and Torney, J.V. (1976). International Human Rights and International Education. Paris, France: U.S. National Commission for UNESCO.

Caduto, M.J. (1985). A guide on environmental values education. Paris, France: UNESCO.

Caride, J.A. (2005). In the name of Environmental Education: words and things in the complex territory of education- environment-development relations. Policy Futures in Education. 3(3), 260-270.

Caro, T.M., Pelkey, N., \& Grigione, M. (1994). Effects of conservation biology education o attitudes toward nature. Conservation Biology. 8, 846-852.

Crawley, M.J. (1993). GLIM for Ecologists. Cambridge, United Kingdom: Blackwell Scientific Publications.

Cuarón, A. D. (1991). Conservación de los primates y sus hábitats en el sur de México. MSc. Thesis. Universidad Nacional, Costa Rica.

Cuarón, A.D. (1997). Land-cover changes and mammal conservation in Mesoamerica. PhD. Dissertation, University of Cambridge, Cambridge, United Kingdom.

Egan, K. (1991). Primary understanding education in early childhood. London: Routledge.

Flores-Villela, O. (1993a). Herpetofauna of Mexico: Distribution and endemism. In T.P. Ramamoorthy, R. Bye, A. Lot, and J. Fa (Ed). Biological Diversity of Mexico: Origins and distribution. (pp. 253-280). New York, U.S.A: Oxford University Press.

Flores-Villela, O. (1993b). Herpetofauna mexicana. Special Publication of the Carnegie Museum of Natural History. 17, 1-73.

Gray, G.G., Larson, J.S. \& Braunhardt D.A.(1979). Urban conservation leadership and the wildlife resource. Urban Ecology. 4, 1-9.

Gray, P. (1991). Psychology. New York: Worth Publishers.

Hardy, T.N. (1988). Entomophobia: The case for Miss Muffet. American Entomological Society. 34, 64-69.

Jacobson, S. K., and. Marynowski S. B. (1997). Public attitudes and knowledge about ecosystem management on Department of Defense land in Florida. Conservation Biology. 11, 770-781.

Kellert, S. R. (1979). Public attitudes toward critical wildlife and natural habitat issues. Washington, D.C: U.S. Government Printing Office and U.S. Fish and Wildlife Service.

Kellert, S. R. (1980). Contemporary values of wildlife in American Society. In W. W. Shaw and I. Zube (Ed.). Wildlife Values Report. (pp. 31-60). Ft. Collins Colorado,USA: U.S. Forest Service. 
Kellert, S. R. (1983). Assessing wildlife and environmental values in cost-benefit analysis. Environmental Management. 18, 355-363.

Kellert, S .R.(1991). Japanese perceptions of wildlife. Conservation Biology. 5, 297-308.

Kellert, S .R. (1993). Values and perceptions of invertebrates. Conservation Biology. 7, 845855.

Kellert, S. R. (1993). The Biological basis for human values of Nature. In R. Kellert and E.O. Wilson. (Ed.) The biophilia Hypothesis. ( pp. 42-69). Washington, D.C: Island Press.

Kellert, S. R. and Clark, T. (1991). The theory and application of a wildlife policy framework. In W.R. Mangun and S .S. Nagel. (Ed.). Public policy and wildlife conservation. (pp. 5-24). New York, USA: Greenwood.

Kohlberg, L. (1984). The psychology of moral development. Essays on moral development. San Francisco, USA: Harper \& Row Publishers.

Laucks, C.E. (1981). The meaning of children. Colorado,USA: Westview Press.

Lockwood, J.A. (1987). The moral standing of insects and the ethics of extinction. Entomology. 70, 70-89.

Loughland, T.,Reid, A. \& Pectocz, P.(2002). Young people's conceptions of environment: A phemonenographic analysis. Environmental Education Research. 2, 187-197.

McNeely, J.A., Miller, K.R.,. Reid, W.V., Mittermeier, R. A. \&. Werner, T. B. (1990). Conserving the world's biological diversity, Gland, IUCN; Washington, USA: WRI, CI, WWF-US, and the World Bank.

More, T. A. (1979). Wildlife preferences and children's books. Wildlife Society Bulletin. 7, 274278.

Morris, D. (1960). An analysis of animal popularity. International Zoo Yearbook 2, 61-67.

Musser, L.M. and Malkus, A.J. (1994). The children's attitudes towards the environment scale. Environmental Education. 25, 22-26.

Nabhan, G. P. and Antoine, St.S. (1993). The loss of floral and faunal story: The extinction of experience. In S. R. Kellert and O.E. Wilson. (Ed.). The biophilia hypothesis. (pp.229250). Washington, D. C.,USA: Island Press.

Oppenheim, A.N. (1992). Questionnaire design, interviewing and attitude measurement. London, U.K: Pinter publishers Ltd.

Piaget, J. (1969). The child's conception of the world. London,U.K: Kegan Paul, Trench, Trubner \& Co.Ltd.

Posch, P. (1993). Research issues in environmental education. Studies in Science Education. $21,21-48$.

Ramamoorthy, T.P., Bye, R.,Lot, A. \& Fa, J.E. (1993). Biological diversity of Mexico: Origins and distribution. Oxford, Oxford University Press.

Rapoport, A.(1978). The environment as an enculturating system: Priorities for environmental research design. Washington. D.C, USA: Weidmann, S. and Anderson, J.A. EDRA.

Reading, R. P., and Kellert, S. (1993). Attitudes toward a proposed reintroduction of black footed ferrets (Mustela nigripes). Conservation Biology, 7, 569-580.

Royal Statistical Society. (1985). GLIM statistical package. U.K.Version 3.77, Royal Statistical Society.

Steel, B. S. (1996). Thinking globally and acting locally?: Environmental attitudes, behavior and activism. Journal of Environmental Management, 47, 27-36.

Sterling, S. 2001. Sustainable Education: Re-visioning learning and change. Devon, U.K: Green Books Ltd.

Titman, W. (1994). Special places special people. London, U.K: WWF-Learning through Landscapes.

Ulrich, R. S. (1993). Biophilia, biophobia, and natural landscapes. In S.R. Kellert and E.O. Wilson. (Ed.). The biophilia Hypothesis. (pp.73-137). Washington, D. C.: Island Press.

Uzzell, D. (1994). Children as catalysts of environmental change. European Commission. Science Research and Development Report. Guilford, Surrey, U.K: University of Surrey.

Van Arcken, M, M. (1993). Environmental education, children and animals. Anthrozoos, 3, 14-19.

Vygotzky, L. (1978). Mind in society. Cambridge, Mass., U.S.A: Harvard University Press. 
Wilson, E.O. (1984). Biophilia: The human bond with other species. Cambridge, Massachussets: Harvard University Press.

Wilson, E.O. (1993). Biophilia and the conservation ethic. In S. R. Kellert and E.O. Wilson. (Ed.). The biophilia hypothesis. (pp. 31-41). Washington, D. C: Island Press. 


\title{
Hayvanlara Yönelik Tutumlar: Meksikalı ve İngiliz Çocuklar Arasında Keşfedici Bir Karşılaştırma
}

\author{
Laura BARRAZA \\ Deakin University, Melbourne, Vic, AUSTRALIA
}

\begin{abstract}
$\mathrm{Bu}$ araştırmada çocukların bazı hayvan türleriyle kurdukları empati ve/veya reddetme ilişkilerini etkileyen faktörlerden bazıları incelenmektedir. Toplumsal bağlamda okulun oynadığı rol göz önünde bulundurulmuştur. 7 ila 9 yaşındaki Meksikalı ve İngiliz çocukların belirli hayvan türlerine karşı tutumları, sadece kültürler ve eğitim sistemleri değil aynı zamanda türler açısından söz konusu olan tutumsal farklılıkların incelenmesi yoluyla karşılaştırılmıştır. Hayvanları içeren ekolojik ikilemler, çocukların ahlaki gelişim ve koruma alanında çevreye ilişkin yorumlarını analiz etmeye yönelik bir yöntem olarak kullanılmıştır. Çocukların, örümcek ve yılanlara yönelik olarak, maymun ve kuşlara göre daha olumsuz tutumlara sahip oldukları görülmüştür. Bu tutumlar kendi içerisinde şaşırtıcı olmasa da bu çalışmada kullanılan materyal ekolojik ikilemlerin kullanımıyla küçük çocukların, koruma konularındaki ahlaki fikirlerini nasıl yapılandırdıklarıyla ilgili yeni bilgiler sağlamaktadır. Çocukların tepkileri kültür, tecrübe, belirli bir hayvana duyulan yakınlık ve okul karakterine göre farklılık göstermektedir.
\end{abstract}

Özet

Anahtar Kelimeler: Tutum, biyofili, çocuk, hayvan, ekolojik ikilem 